Polar Record

www.cambridge.org/pol

\section{Introduction}

Cite this article: Thisted $\mathrm{K}$, Sejersen $\mathrm{F}$, and Lien ME. Arctic Uchronotopias: Resource extraction, community making and the negotiation of Arctic futures. Polar Record 57(e28): 1-4. https://doi.org/10.1017/ S0032247421000231

\section{Keywords:}

Extractivism; Emotions; Place-making; Visions of the future; Politics of ontology; Indigenous peoples

Author for correspondence: Kirsten Thisted, Email: thisted@hum.ku.dk

\title{
Arctic Uchronotopias: Resource extraction, community making and the negotiation of Arctic futures
}

Kirsten Thisted ${ }^{1}$, Frank Sejersen ${ }^{1}$ and Marianne Elisabeth Lien $^{2}$

${ }^{1}$ University of Copenhagen, København, Denmark and ${ }^{2}$ University of Oslo, Oslo, Norway

\section{Introduction}

This special collection offers an affective focus on mining and extractivism in the Nordic Arctic. The Arctic has a long history of extractivism. Depicted as a region of untapped natural plenty, it has been seen as "up for grabs" within different kinds of political regimes, but also as a pristine environment in need of protection. This history of extractivism is intertwined with a legacy of colonialism that marks the history of the Nordic Arctic as well as the Arctic more generally (Hastrup and Lien 2020, Bravo and Sörlin 2002).

Despite the wide differences in political ways of approaching extractive projects, there is a consensus about the role of emotions in such endeavours: emotions should be avoided in mining issues. Instead, mining discussions should be based on facts and so-called rational arguments related to spheres such as environment, economy, development, labour market, etc. As formulated by a frustrated (and highly emotional) director of the Swedish mining company Arctic Gold:

We are of course both sad and surprised that the majority of the Municipality Council did not listen to our arguments that this would be a good project. We think it is stupid that we were not given the permission to start an environmental impact assessment, so facts could be laid on the table. As it stands now, people are voting with their heart (Vuolab and Gaup 2013, as quoted in Kramvig and Avango 2021, this issue).

"Voting with one's heart" is here used as a metaphor for emotions, equivalent to the irrationality that prevents facts and thus reasoning from triumphing. The distinction between reason and feeling is a century-long tradition in Western European culture (Abu-Lughod \& Lutz 1990; Dixon 2003). This has formed the basis for governance and justified political decisions through a shared valuation of logical arguments. Hence, those agents (be it industry, politicians, stakeholders or rights holders) who manage to set the framework that distinguishes rational arguments from those that must be dismissed as emotional or irrational have the upper hand. Similarly, those who are able to draw on what is considered facts, rather than assumptions or mere "beliefs," and those who are in a position to mobilise science to support their case, will have a better chance of shaping the outcome of a mining controversy. Extractivism thus rests upon, and reinforces, the cultural distinction between reason and emotion, and between science and politics.

As the contributions to this special collection demonstrate, the contradictions between the sense of the mining industry and the sensibilities of possible opponents rest on a false contradiction. Emotions are at play whenever mining is an issue. Mining companies' slogans about "opportunities" and "potentials" are good examples of the circulation of positive emotions in the form of dreams and hopes. Whether to mine or not depends on different visions of the future, different hopes, different ideas of what might be "the good life" - all of which is deeply embedded in emotion. Thus, emotions affect how the industries are anticipated, planned and managed. Focusing on resource-making in the Nordic Arctic, Hastrup and Lien have proposed the term welfare frontiers to point to state' efforts to advance and realise particular democratic visions of good living conditions in regions seen as marginal (2020:vii). They also show how making landscapes resourceful entails significant emotional investment. Nevertheless, the productive work that emotions do in such processes is rarely investigated.

This special collection explores how humanities and the social sciences can be applied to the field of mining and extraction studies, which is otherwise dominated by the natural sciences (geology, metallurgy, engineering, etc.) and economics. The articles draw on critical cultural studies, critical human geography, relational ontology, social psychology and anthropological approaches to affect and emotion. By doing so, they cast new light on the issues, which are normally in focus when researching and understanding mining. Thus, this special collection has the ambition to approach mining questions linked to development (e.g. economic), trade-offs (e.g. environmental), barriers (e.g. infrastructural), requirements (e.g. technical), community relations (e.g. stakeholder participation), control (e.g. legislation), inequalities (e.g. access to consultants and lawyers) and opportunities (e.g. employment) in a novel and productive way that bypasses the normal frameworks, which set the arena for mining discussions. 
Without emotions - hope, longings and dreams - there are no resources, only stuff in the ground. This has made scholars talk about "abstractive industries" (Mason 2016) or the so-called "economy of appearance" (Tsing 2000) when analysing this more elusive aspect of extractive activities. Companies not only extract raw materials from nature, engendering hope and "hype," they also reconfigure relations between people and land, sometimes severing ongoing relations of reciprocity, or redistributing local opportunities for making a living through irreversibly changing the natural surroundings. Through such processes extractivism triggers and feeds into an affective relational field, triggering emotions across a broad spectrum. Elsewhere, we suggest the term "mining emotions" as a denominator for this interconnected process, whereby people - embarking on certain projects - make themselves committed to specific futures (Sejersen and Thisted 2021). Through the emotional productions and workings of time and space, different demarcations and scales of communities and places are constructed and made sensible - such as in the Greenlandic case where extraction is interlinked with nation-building or even state formation. Consequently, the concept of "mining emotions" draws our attention to the negotiations and translations that evolve in usually highly contested settings where contrasting visions for a particular place struggle to achieve supremacy.

Inspired by the Russian semiotician Mikhail Bakhtin's timespace (chronotope) concept, the historian Hagen SchultzForberg (2013) has coined the concept "Uchronotopia" for such narratives connecting place with a vision for a perfect time to come. No question today seems more important in the Arctic than the struggle for visions for the future. The main purpose of this special collection has been to uncover these struggles in different settings, and we have therefore borrowed Schultz-Forberg's concept for our title. Following human geographer Doreen Massey's call to see space as a meeting up of a multiplicity of trajectories and histories, the authors investigate how communities are imagined and (re) constructed through the affective practices embedded within these histories, creating forms of belonging as well as alienation, solidarity as well as polarisation. With a performative approach to community making, the authors challenge the ontological status of community as fixed or stable. This opens up for a dynamic understanding of community, which may also imply non-social entanglements, and often involve questioning and contesting conventional modes of performing "the real." The authors thus work with ontological politics rather than simply identity politics, and stakeholder interests, and trace the ways in which ontological politics unfold, often somewhat unnoticed, and sometimes as an inherent and pivotal aspect of identity politics.

The articles investigate cases where indigenous peoples are involved. However, the situation of indigenous peoples vary in different parts of the world, as also the articles in this special collection demonstrate. Even within the otherwise relatively homogeneous Scandinavia, the Greenlanders have completely different political conditions than the Sámi in Norway, Sweden and Finland. While the Sámi have status as ethnic minorities within the Scandinavian countries, although with rather different forms of sovereignty in relation to the land, the Greenlanders are in the majority in their country. With the Act on Greenland Self-Government of 2009, they not only have the rights to minerals and water, they also have the right to leave the Danish Kingdom and create their own nation state whenever they so may decide. Even when the land is, in principle, the property of the local inhabitants and the Sámi population, through legal structures such as the Finnmark property (FEFO, see e.g. Ween and Lien 2012), the subsoil is usually not. However, legal regulations ensure that local governing bodies (municipalities, FEFO, as well as the Sámi parliament) have a say in relation to the permissions necessary for mining. This makes mining a political issue which cuts across ethnic divisions. Indigenous peoples' rights are often mobilised in relation to mining in Sápmi, unlike in the Greenlandic debate where it plays a fairly minor role. Here, mining is staged as a means to create the economic basis for growth and national independence. Drawing on community fieldwork, stakeholder interviews, political documents, media representations and public narratives, the contributions analyse this highly contested field of indigenous peoples' rights, processes of self-determination and nation-building, resource extraction and management.

The three articles by Lien (2021, this collection), Kramvig and Avango (2021, this collection), as well as Ween (2021, this collection) investigate disputes and conflicts in the utilisation of land and water in Sápmi, northern Scandinavia. Focusing on the expansion of a quartzite quarry at Austertana/Juovlavuotna, proposed by the Elkem mining company, Lien's article investigates the multiple interruptions such an expansion will cause to the Giemaš mountain, the nearby community and the life forms and beings located there. Not only will the routes of migrating birds, reindeer and salmon be affected, but also the powers supposed to reside in the area must be taken into consideration. Thus, various manifestations of the real and the ways in which ontological claims about unspeakable forces can be talked about, or carefully silenced, become part of the emotional controversies underlying political discussions on the future of the place. On a similar note, Kramvig and Avango investigate how different political ontologies, not different interests, are the basis of conflict over the reopening of the Biedjovággi copper mine at Guovdageaidnu. Arguing that traditional land use and Sámi understanding of the land are being mistranslated and displaced in official documents, the article points to translation as a site where colonial difference in ways of knowing are manifest. Ween starts by describing an art installation called "The Map Machine." This consisted of a stainless steel frame with nine sheets of plexiglass to be moved along nine rails; each sheet containing a map representing a different legend, all defining the same landscape. Thus, the installation demonstrated how different cartographic visions of the same landscape compete, making visible the incompatibility of the many ambitions of stakeholders and mapmakers alike. Analysing the work of bureaucratic procedures put into action by the Elkem Industries' alleged need to enlarge the seaway approach to the quartzite mine, and the Norwegian Coastal Administration's plan to fund this, Ween uses "the Map Machine" as a metaphorical device. The article demonstrates how laws and documents aiming at nature protection do not necessarily benefit local or indigenous interests, since the whole procedure with hearings and reports all become part of the same bureaucratic trail, based on one particular framing of the landscape. "Regardless of which cartographic vision a bureaucratic procedure brings into focus, other aspects of the same land-water interfaces are set aside, and inevitably, some local inhabitants are sacrificed."

The three articles by Sejersen (2021, this collection), Thisted (2021, this collection) and Bjørst (2021, this collection) analyse mining politics in self-governed Greenland since 2009. Sejersen investigates how two prominent Greenlandic Premiers in each their way have translated hard rock into soft human welfare. As an analytical ordering device Sejersen coins the concept "brokers of hope," in order to point the analytical attention to the entrepreneurial activities of indigenous politics. Furthermore, the article 
investigates how ideas of future cooperation with Chinese partners are used to challenge and transform existing asymmetrical relations between Denmark and Greenland. On a similar note, Thisted analyses the Danish-Greenlandic debate on Greenland's plans to extract and export uranium. Borrowing cultural theorist Sara Ahmed's term "happy objects" (Ahmed 2010), the article demonstrates how uranium has become a "happy object" in the Greenlandic debate on secession from Denmark, promising the Greenlanders not only future prosperity, but also release from the emotional economy, which characterises postcolonial relations between Denmark and Greenland. While opponents to uranium mining are positioned as "affect aliens" or "killjoys" in the independence discourse, disappointed expectations of rapid economic progress and growing distrust of large-scale projects have sparked a discussion about the meanings of the concept of "independence." Focusing on the resistance movement, Bjørst shows how this has gained momentum in Greenland and Denmark and has been successful in identifying "objects of fear" towards mining - especially the mining of Greenland's uranium. This creates problems in relations - and partnerships building, which have become so crucial in the mining industry and the political future-making process connected thereto. From the point of view of the uranium opponents, the partnerships between Greenland and the mining companies appear as a neocolonial repetition of colonialism. From the supporters' point of view, the stories of fear are hindering a successful partnership with the industry, and the citizens are the victims, not to the impact of mining, but to the lack of development and investments. The article thus demonstrates, how all actors are emotionally invested whether they talk about mining as something that will save or destroy the local community.

Jørgensen (2021, this collection) compares cases from Greenland and Sápmi, respectively: the former mining city of Qullissat in the Greenlandic Disko Bay area and the rural village of Sakajärvi threatened by expansions of the Aitik coppermine in Swedish Norbotton. The article develops the concept "communitification," in order to underline the performative aspect of the community concept. Further, the verbalised form addresses the agency embedded in the boundary-making of communities, so powerful in the shaping of social realities, but often executed more or less inadvertently. In her analysis, which points at how it is the planned extension of the mine that creates a strong community in the Sámi case, but the closure of the mine in the Greenlandic case, Jørgensen investigates the role of emotions and affective economies in the communitification process. The analysis demonstrates how communities depend widely on the intensity of the emotions invested, and how emotions create a symbolic capital that may hold considerable potential for creating desirable futures.

Finally, Askland (2021, this collection) contributes with an article about the small village of Wollar in the Mid-Western Region of New South Wales, Australia. Although the context is different, there are nevertheless obvious similarities with the Arctic cases. Askland uses the notion of "voids," both as mining phenomenon and as metaphor, in order to explore how visions of the future form part of narratives and experiences of mineral extraction. To environmental activist campaigns that hook on to hashtags and slogans, such as \#keepitintheground, \#timetochoose, \#waterislife and \#systemchangenotclimatechange, the sense of crisis and urgency due to climate change is central. However, to the people living at the coal face, the fight against the developmental and growth discourses of the extraction industries rather relates to how mining has dug, not only dirt and mineral, but people and emotion out of place. It has left a void - physical, social and temporal - where affective imaginings of a future place are colonised by a rationalist mining discourse.

Work on the articles in this special collection has been carried out within the framework of the research project Resource Extraction and Sustainable Arctic Communities (REXSAC), which is one of four Nordic Centres of Excellence in Arctic research funded by Nordforsk for the period 2016-2020 under the programme Responsible Development of the Arctic: Opportunities and Challenges - Pathways to Action. This collection is the result of cooperation between three research task groups within the REXSAC project: RT 3, Governance structures for extractive industries: Identifying path dependencies; RT 5, Affective economies: How are places, communities and identities constructed? and RT 8, Co-existences: Recoding natural resources for future livelihoods.

Please visit the project home page at https://www.rexsac.org/

\section{References}

Abu-Lughod, L., \& Lutz C. A. (1990). Introduction: emotion, discourse, and the politics of everyday life. In L. Abu-Lughod, \& C. A. Lutz (Eds.), Language and the politics of emotion (pp. 1-23). New York: Cambridge University Press.

Ahmed, S. (2010): The Promise of Happiness. Durham, NC: Duke University Press.

Askland H. H. (2021, this collection). Mining voids: extraction and emotion at the Australian coal frontier. Polar Record, 56(e5), 1-10.. doi: 10.1017/ S0032247420000078

Bjørst L. R. (2021, this collection). Stories, emotions, partnerships and the quest for stable relationships in the Greenlandic mining sector. Polar Record, 56(e23), 1-13. doi: 10.1017/S0032247420000261

Bravo, M., \& Sörlin, S. (Eds.) (2002), Narrating the Arctic. A Cultural History of Nordic Scientific Practices. Canton, MA: Science History Publications.

Dixon, T. (2003). From Passions to Emotions. The Creation of a Secular Psychological Category. Cambridge: Cambridge University Press.

Hastrup, F., \& Lien, M.E. (2020): Welfare frontiers? Resource practices in the Nordic Arctic Anthropocene. Anthropological Journal of European Cultures, 29(1), v-xxi.

Jørgensen, A.-M. (2021, this collection). Communitification and emotional capital: producing, shaping and re -shaping communities before and after mining in Norrbotten and Disko Bay. Polar Record, 56(e7), 1-11. doi: 10. $1017 /$ S0032247419000548

Kramvig, B., \& Avango, D. (2021, this collection). Interruptions: epistemic formations and anticipated extraction at Giemaš, Norway. Polar Record, $56(\mathrm{e} 5), 1-10$.

Lien, M. E. (2021, this collection). Interruptions: affective futures and uncanny presences at Giemaš, Finnmark. Polar Record, 57(e1), 1-9. doi: 10.1017/ S0032247420000443

Mason, A. (2016, July 29). Introduction: assembling the valuable and vulnerable North. Cultural Anthropology. Retrieved from https://culanth.org/fieldsights/ 938-introduction-assembling-the-valuable-and-vulnerable-north.

Schulz-Forberg, H. (2013). Time and again toward the future. Claims on time as a new approach for global history. In H. Schulz-Forberg (Ed.), Zero hours. Conceptual insecurities and new beginnings in the interwar period (pp. 15-49). Brussels: P.I.E. Peter Lang.

Sejersen, F. (2021, this collection). Brokers of hope: extractive industries and the dynamics of future-making in post-colonial Greenland. Polar Record, 56(e22), 1-11. doi: 10.1017/S0032247419000457

Sejersen, F., \& Thisted, K. (2021). Mining emotions- affective approaches to resource extraction. In D. C. Nord (Ed.), Nordic perspectives on the responsible development of the Arctic: Pathways for action (pp. 369-389). Cham, Switzerland: Springer.

Thisted K. (2021, this collection). Emotions, finances and independence: Uranium as a "happy object" in the Greenlandic debate on secession from Denmark. Polar Record, 56(e1), 1-12. doi: 10.1017/S0032247419000433 
Tsing, A. L. (2000). Inside the economy of appearance. Public Culture, 12(1), $115-144$.

Vuolab, S. E., \& Gaup, B. S. (2013). Trist og forunderlig. Direktør Lars-Åke Claesson i det svenske gruveselskapet Arctic Gold er svært skuffet etter at politikerne i Kautokeino i dag har avgitt sitt gruve-nei. NRK Sápmi 16. December 2013. https://www.nrk.no/sapmi/arctic-gold-skuffet-over-gruvenei-1.11421746 [accessed 12 April 2020].
Ween, G. (2021, this collection). The map machine: Salmon, Sámi, sand eels, sand, water and reindeer. Resource extraction in the High North and collateral landscapes. Polar Record, 56(e19), 1-10. doi: 10.1017/S003224742 0000236

Ween, G. B., \& Lien, M. E. (2012). Decolonialization in the Arctic? Nature practices and land rights in the Norwegian High North. Journal of Rural and Community Development, 7 (1), 93-109. 